\title{
PENGARUH MASSED PRACTICE TERHADAP KEMAMPUAN PASSING BOLA BASKET SISWA EKSTRAKURIKULER SMP NEGERI 11 KOTA JAMBI
}

\author{
Boy Indrayana \\ Fakultas Ilmu Keolahragaan, Universitas Jambi, Jambi, Indonesia \\ Correspondence: Fakultas Ilmu Keolahragaan, Universitas Jambi, Jambi, Indonesia. \\ E-mail: boy.indrayana@yahoo.co.id
}

\begin{abstract}
The purpose of this study was to determine the effect of massed practice the passing ability of basketball student extracurricular basketball SMP Negeri 11 Jambi. Passing or operand is the basic techniques in ball games by giving the ball to the comrades in the game of basketball. Mastery of the basic techniques of passing is an important element that must be mastered by every basketball player in the game. The learning method massed practice is practice methods that can be applied in basketball. Massed practice method is a method / strategy study the movement to be controlled is done continuously without breaks interspersed The method used is an experimental method with a sample of 16 male students. the sampling technique is done by total sampling. This study begins with a pre-test and post-test ends with the passing ability of basketball. It was done for 6 weeks with a frequency of three times a week. This research hypothesis testing using t-test at level $\alpha=0.05$ which is the right of the preconditions that the sample group were normally distributed and homogeneous. After the t-test results obtained t-count (16.284)> $t$ table $=(1.753)$ as obtained $t$-count $>$ t-table, so the hypothesis (Ha) in this study received the 95\% confidence level. Based on the results of research and discussion that has been done, it can be concluded that massed practice given significant impact to improve the ability of students passing basketball extracurricular basketball SMP Negeri 11 Jambi.
\end{abstract}

\section{Kata Kunci: Massed Practice Passing Basketball}

\section{PENDAHULUAN}

Olahraga dapat meningkatkan kesehatan dan status kebugaran jasmani para pelakunya. Tidak dapat dipungkiri bahwa olahraga telah banyak memberikan sumbangannya untuk kebugaran umat manusia. Berbagai jenis olahraga dapat dilakukan manusia. Salah satu olahraga yang sampai saat ini masih digemari oleh masyarakat dan masih populer sampai sekarang adalah permainan bola basket. Dalam permainan bola basket seseorang dituntut untuk selalu bergerak sambil memperagakan teknik teknik yang ada dalam bola basket, berusaha memasukkan bola ke ring lawan sebanyak banyaknya tanpa mendapat gangguan dari lawan serta berusaha mencegah lawan untuk memasukkan bola ke dalam ring.

Permainan bola basket dapat dilaksanakan apabila, seorang pemain memiliki suatu keterampilan (skill) yang sempurna yang dilatih secara disiplin, teratur, berjenjang dan berkesinambungan. Ketepatan dalam menentukan metode latihan dapat mempengaruhi 
tingkat pencapaian dari tujuan latihan. Metode pembelajaran massed practice adalah metode praktek yang bisa diterapkan dalam bola basket. Metode massed practice adalah suatu cara/strategi mempelajari gerakan agar dapat dikuasai yang dilakukan secara terus-menerus tanpa diselingi istirahat.

Di SMP Negeri 11 Kota Jambi peneliti melihat dalam permainan basket ini kemampuan siswa masih kurang dalam melakukan passing dengan baik, beberapa kendala yang dihadapi siswa antara lain masih lemahnya kekuatan otot lengan pada saat melempar, kemampuan menguasai teknik yang belum memadai, kekuatan otot tangan yang belum seimbang saat mengoper, program latihan yang asal asalan dan kegiatan latihan yang tidak sistematis, di lihat dari hasil permainan siswa itu sendiri kemampuan gerak mereka masih terbatas dan masih kaku, sehingga pada saat mengoper bola tidak sesuai dengan yang diharapkan.

Sesuai dengan yang diuraikan diatas maka peneliti tertarik untuk melakukan penelitian dengan tujuan mengatasi masalah dalam latihan passing bola basket dengan judul " Pengaruh Massed Practice Terhadap Kemampuan Passing Bola Basket Siswa Ekstrakurikuler Bola Basket SMP Negeri 11 Kota Jambi”.

\section{Hakekat Bola Basket}

Bola basket sudah berkembang pesat sejak pertama kali diciptakan pada akhir abad ke-19. Dr. James A. Naismith, seorang guru pendidikan olahraga di YMCA International Training School ( kini Springfield College ), menciptakan olahraga bola basket pada musim gugur tahun 1891. Naismith diberikan tugas oleh penyelianya, Luther H. Gulick, untuk menciptakan sebuah permainan dalam ruangan yang membantu para siswa untuk tetap aktif dan bugar selama bulan-bulan yang dingin pada musim dingin di Massachusetts. Bola basket adalah salah satu olahraga yang paling digemari oleh penduduk Amerika Serikat dan penduduk dibelahan bumi lainnya, antara lain di Amerika Selatan, Eropa Selatan, Lithuania dan juga Indonesia. Banyak kompetisi bola basket yang diselenggarakan setiap tahun seperti British Basketball League (BBL) di Inggris, National Basketball Association (NBA) di Amerika, dan National Basketball League ( NBL) di Indonesia ( oliver, 2007:2).

Dengan demikian yang dimaksud dengan bola basket dalam penelitian ini adalah olahraga yang dimainkan dengan menggunakan tangan dan memasukkan bola kedalam ring ( basket ). Sesuai dengan kutipan di atas dapat disimpulkan bahwa keterampilan seorang pemain dalam menampilkan berbagai gerakan pada permainan bola basket sangat ditentukan pada seberapa besar penguasaan teknik teknik dasar yang dikuasai. Salah satu teknik yang harus dikuasai adalah passing. Sebab, kemampuan seorang pemain dalam mengoper bola sangat menentukan keberhasilan suatu tim dalam memenangkan pertandingan.

\section{Teknik Dasar Bola Basket}

Teknik dasar merupakan unsur dasar yang harus dikuasai pemain untuk mencapai prestasi dalam permainan bola basket. Menurut Sodikun ( 1992 : 49 ) teknik dasar dalam permainan bola basket terdiri dari :

1. Operan dan tangkapan ( passing dan catching )

2. Menggiring (dribbling )

3. Menembak ( shooting)

\section{Kemampuan Passing Bola Basket}

Kemampuan berasal dari kata mampu yang berarti berkuasa ( bisa, sanggup) melakukan sesuatu, sedangkan kemampuan berarti kesanggupan, kecakapan, kekuatan. 
Menurut Muhammad Zain dalam Milman Yusdi ( 2010:10) mengartikan kemampuan adalah kesanggupan, kecakapan kekuatan kita berusaha dengan diri sendiri.

Dari pendapat di atas dapat disimpulkan bahwa kemampuan adalah kesanggupan, kecakapan dan kekuatan seorang individu untuk melakukan beragam tugas dalam suatu pekerjaan.

\section{Passing Bola Basket}

Istilah melempar mengandung pengertian mengoper bola dan menangkap artinya menerima bola. Melempar bola dan menangkap bola selalu dilakukan secara berteman, apabila seorang pemain memegang bola maka dia harus melempar bola sedangkan pemain dalam posisi tidak memegang bola maka dia bersiap untuk menerima atau menangkap bola.

Passing atau operan adalah teknik dasar dalam permainan bola dengan cara memberikan bola kepada kawan dalam permainan bola basket. dalam menangkap bola harus diperhatikan agar bola dalam penguasaan. Bola dijemput telapak tangan dengan jari-jari tangan terlentang dan pergelangan tangan rileks. Saat bola masuk diantara kedua telapak tangan, jari tangan segera melekat ke bola dan ditarik kebelakang atau mengikuti arah datangnnya bola.

Dari pendapat diatas dapat disimpulkan passing adalah teknik dasar yang harus dimiliki oleh setiap pebasket yang digunakan untuk memberikan bola kepada kawan dengan cara dilempar dan memudahkan untuk mencetak angka.

\section{Hakekat Latihan}

Kondisi fisik yang baik merupakan faktor yang mendasar untuk mengembangkan faktor lainnya, sehingga akan mendukung pencapaian prestasi yang optimal. Latihan olahraga merupakan pengertian dari semua usaha dalam proses meningkatkan prestasi, termasuk pula semua usaha untuk mempertahankan. latihan merupakan kegiatan yang sistematis dalam waktu yang lama ditingkatkan secara progresif dan individual yang mengarah kepada ciri ciri fungsi fisiologis. Latihan merupakan suatu proses kegiatan yang dilakukan berulang ulang dan dengan tujuan untuk meningkatkan respon fisioligi terhadap intensitas, durasi dan frekuensi latihan, keadaan lingkungan dan status fisiologis individu.

Agar tujuan latihan dapat dicapai secara optimal, hendaknya diterapkan prinsip prinsip latihan yang baik dan tepat.
a. Prinsip Beban Lebih (overload principle)
b. Prinsip penggunaan beban secara progresif
c. Prinsip pengaturan latihan
d. Prinsip individual
e. Prinsip kekhususan

\section{Metode Massed Practice}

Untuk mencapai tingkatan kemampuan yang maksimal, maka seorang atlit sebaiknya melakukan pengulangan gerakan dengan frekuensi sebanyak banyaknya. Melakukan gerakan gerakan yang dipelajari maka, akan terjadi gerakan otomatisasi yang efektif dan efisien. Latihan dengan metode padat atau terus menerus dapat juga disebut massed practice. latihan dengan massed practice adalah praktek suatu keterampilan olahraga yang dipelajari dilakukan dengan berkesinambungan dan konsisten tanpa diselingi waktu istirahat. 
Latihan terus menerus sebagai suatu bentuk latihan dimana waktu yang diberikan untuk istirahat diantara bagian bagian kegiatan tersebut lebih pendek daripada waktu yang disediakan untuk melakukan satu bagian dari kegiatan latihan. 


\section{Metode}

Penelitian ini dilaksanakan di SMP Negeri 11 Kota Jambi. penelitian dilakukan sebanyak 18 kali pertemuan dilaksanakan pada bulan 18 november 2015 - 18 januari 2016, dengan frekuensi latihan 3 kali seminggu.

Penelitian ini menggunakan metode penelitian eksperimen ( uji coba ). Adapun rancangan penelitian ini menggunakan rancangan One Group Pre test-post test Design.

Adapun yang menjadi variabel dalam penelitian ini adalah :

a. Variabel bebas yaitu massed practice yang terdiri dari :

1. Passing dengan teknik chest pass

2. Passing dengan teknik bounce pass

3. Passing dengan teknik overhead pass

b. Variabel terikat yaitu kemampuan passing bola basket

Teknik pengumpulan data pada penelitian ini adalah dengan cara teknik tes yang terdiri dari tes awal dan tes akhir. Sebelum melakukan tes, sampel terlebih dahulu dikumpulkan dan diberi penjelasan. Tes awal dilakukan sebelum diberi perlakuan yang bertujuan untuk melihat keberhasilan passing awal siswa. Sedangkan tes akhir adalah tes yang dilakukan sesudah diberikan perlakuan, kemudian diberikan tes akhir yang bertujuan untuk melihat keberhasilan melakukan passing bola basket. Analisis data dilakukan untuk menguji hipotesis penelitian membandingkan skor tes awal (pre test) dengan skor tes akhir (post test).

\section{Pembahasan}

Deskripsi data adalah hasil yang diperoleh dari tes Passing Chest Pass siswa ekstrakurikuler bola basket SMP Negeri 11 Kota Jambi. Kelompok eksperimen berjumlah 16 orang sampel siswa putra dilakukan perhitungan rata-rata, simpangan baku, kemampuan terbaik, kemampuan terburuk dan rentang. Hasilnya secara lengkap terlihat seperti pada tabel berikut ini:

\begin{tabular}{|c|c|c|c|c|c|c|}
\hline $\begin{array}{c}\text { Sumber } \\
\text { Variasi }\end{array}$ & $\mathbf{N}$ & $\begin{array}{c}\text { Rat } \\
\text { a- } \\
\text { rata }\end{array}$ & $\begin{array}{c}\text { Simpangan } \\
\text { baku }\end{array}$ & $\begin{array}{c}\text { Kemampuan } \\
\text { Terbaik }\end{array}$ & $\begin{array}{c}\text { Kemampuan } \\
\text { Terburuk }\end{array}$ & $\begin{array}{c}\text { Rentan } \\
\mathbf{g}\end{array}$ \\
\hline Test awal & 1 & 21,1 & 3,5 & 27 & 17 & 10 \\
& 6 & 25 & & & & 11 \\
\hline Test akhir & 1 & 27,3 & 3,28 & 32 & 21 & \\
& 6 & 75 & & & & \\
\hline
\end{tabular}

Tabel 4.1 pre test dan post test

Dalam pelaksanaan penelitian ini, tes dilakukan sebanyak 2 kali yaitu tes awal dan tes akhir. Tes awal yang dilakukan bertujuan untuk melihat kemampuan awal seseorang sebelum diberikan perlakuan dan tes akhir yang dilakukan bertujuan untuk melihat sejauh mana pengaruh latihan massed practice terhadap kemampuan passing bola basket siswa ekstrakurikuler bola basket SMP Negeri 11 Kota Jambi. Latihan dilakukan dengan perlakuan 3 kali seminggu selama 18 kali pertemuan.

Dari analisis statistik pada pengujian menunjukan pengaruh latihan massed practice dapat meningkatkan kemampuan passing bola basket, hal ini disimpulkan berdasarkan hasil analisis data uji statistik-t eksperimen diperoleh $t_{\text {hitung }}=16,284$ harga tersebut dibandingkan 
dengan harga $t_{\text {tabel }}$ dengan df : n-1 $(16-1=15)$. Pada taraf signifikan $\alpha=0,05$. Adalah 1,753. Dengan demikian $t_{\text {hitung }}>t_{\text {tabel }}$ maka hipotesis alternatif (Ha) yang dikemukakan dalam penelitian ini diterima kebenaranya.

Berdasarkan pada hasil tes awal diperoleh kemampuan passing dengan rata-rata 21,125 dan simpangan baku 3,5. Sedangkan data tes akhir eksperimen diperoleh rata-rata 27,375 dengan simpangan baku 3,28. Dengan demikian dapat dikatakan bahwa hipotesis yang diungkapkan dalam penelitian ini dapat diterima kebenarannya.

\section{Kesimpulan}

Berdasarkan hasil analisis data yang dilakukan hasil nilai rata-rata tes awal dan tes akhir serta simpangan baku tes awal dan tes akhir mengalami peningkatan yang signifikan, dengan analisis uji-t $t_{\text {hitung }}>t_{\text {tabel }}$ maka dengan demikan Ha diterima dan dapat disimpulkan bahwa terdapat pengaruh massed practice terhadap kemampuan passing bola basket siswa ekstrakurikuler bola basket SMP Negeri 11 Kota Jambi.

\section{Referensi}

Arikunto Suharsimi, Prosedur Penelitian Suatu Pendekatak Praktik. Jakarta: Bina Aksara, 1989.

Bompa O. Tudor, Theory and Methodology of training: The Key to Atletic performance Second edition Dubuque Iowa: Kendal//Huns Publishing Company, 1990.

Danny Kosasih, Fundamental Basketball First Step To Win. Semarang: Karangturi Media, Yayasan Pendidikan Nasional Karangturi, 2008.

Drowatzky John N, Motor Learning Principles and Practices (second edition). Ohio: Burgess Publishing of Toledo, 1981.

Imam Sodikun, Olahraga Pilihan Bola Basket. Jakarta: Depdikbud Dirjen Dikti Proyek Pembinaan Tenaga Kependidikan, 1992.

Harsono, Choaching dan Aspek-Aspek Psycologis dalam Olahraga. Jakarta: PT. Raja GrafindoPersada, 1988.

Lamb D. R, Physiology of Axsecise Responses and Adaptions. Canada: Mac Milk Publising Campany, 1984.

Oliver Jon, Dasar-Dasar Bola basket. Bandung: Pakar Raya, 2007.

PB. PERBASI, Peraturan Resmi Bola Basket. Jakarta: Perbasi, 2010.

Sajoto, Pembinaan Kondisi Fisik Dalam Olahraga. Semarang: Dahara Prize, 1995.

Santosa Bayu, Perbedaan Pengaruh Latihan Dengan Metode Massed Practice dan Distributed Practice. Surakarta: UNSEMAR, 2011.

Saputra Dwi, Pengaruh Latihan Padat Terhadap Kemampuan Dribbling. Bengkulu: Universitas Bengkulu, 2014.

Schmidt A. Richard, Motor Skill. New York: Harper and Row Publisher, 1986.

Wissel Hall, Bola Basket: Langkah Untuk Sukses. Jakarta: Grafindo Persada, 2000. 